\title{
The Central Valley Project and the Farmers
}

\author{
Edson Abel*
}

\section{The Historical Purpose-Irrigation}

The Central Valley Project had its inception in the dire need for additional irrigation water on the part of Southern San Joaquin Valley irrigators. It was their distress which inspired the initial appropriation by the California Legislature for an investigation of Calfornia's water resources. ${ }^{1}$ The investigation culminated in a plan issued by the Division of Water Resources in $19300^{2}$ This was transmitted to the legislature and designated as the "State Water Plan." 3 The plan contains the following: 4

\begin{abstract}
A report containing a complete inventory of all water within the state's boundaries, an estimate of the gross agricultural area, and of the average amount of water that should be applied for irrigation, and a general preliminary comprehensive plan for "converting the waters of Cahifornia to their greatest service in this generation and for all posterity," was filed with the 1923 Legislature. It was found in this investigation that the principal constructive features of a plan for obtaining maximum use of the state's water inust revolve about its distribution for the greatly preponderant use in agriculture.
\end{abstract}

In 1933, the legislature passed the Central Valley Project Act ${ }^{5}$ which embodied those parts of the State Water Plan which had been devised to solve what were recognized as the most urgent of the water shortage problems. This statute authorized the construction of Kennett (Shasta) and Friant Dams, the San Joaquin pumping system

\footnotetext{
*Assistant Director, Public Utilities Department, California Farm Bureau Federation.

${ }^{1}$ Cal. Stats. 1921 , c. 889.

2 CAL. Div, of WATER Resources, Report to Legislature of 1931 on State Water Pran, Bulletin No. 25 (1930).

3 Pursuant to Cal. Stats. 1929, c. 832 and CaL. Water Code $\$ 10000$.

4 CaL. Div. of Water Resources, op. cit. supra note 2, at 24-25. Earlier, State Engineer W. F. McClure had transmitted to the legislature "an economic program of physical works for the importation of water into Tulare County," which he referred to as "a first unit of this comprehensive plan for the relief of some needy section of the State." CaI. Div. of Engineering and Irrigation, Supplementary Report on Water Resources of CALLFORNIA, Bulletin No. 9 (1925).
}

5 Cal. Stats. 1933, c. 1042. 
and the Contra Costa, IVIadera and Friant-Kern Canals. It is interesting to note that in its policy provisions that statute called for "incidental generation, transmission and distribution of electrical energy" and stated: ${ }^{6}$

In addition to the works specified in the foregoing subdivisions said units shall include such plants and works for the generation of electric energy by steam or other power, and such electric transmission lines and facilities for the sale, use and distribution of electric energy as are determined by the authority to be necessary for unaking a reasonable, proper and advantageous sale, use and distribution of electric energy made available by said units.

These policy indicators have been carried forward in Sections 11125 and 11295 of the State Water Code.

The Central Valley Project Act was victorious over a referendum and the Water Project Authority which it created for the administration of the project continues to function even though at least temporarily bereft of its charge. The authority was authorized to issue $\$ 170,000,000$ in revenue bonds, the proceeds from which were expected to cover the construction costs of the project. Economic conditions in 1934 and 1935 caused the state to seek federal assistance in the construction of the project by application for its inclusion in the projects aided by the Federal Public Works Administration, an executive creation under the National Industrial Recovery Act of 1933. An allocation of funds was made under this procedure with the provision that they should be "reimbursable in accordance with the reclamation laws." The Bureau of Reclamation set up a project office in Sacramento on October 25, 1935.

This executive action was given legislative confirmation in the Rivers and Harbors Act of 1937,8 in which the project was reauthorized "and declared to be for the purposes of improving navigation, regulating the flow of the San Joaquin River and the Sacraniento River, controlling floods, providing for storage and for the delivery of the stored waters thereof ... f for the reclamation of arid and semiarid lands and lands of Indian reservations, and other beneficial uses, and for the generation and sale of electric energy as a means of financially aiding and assisting such undertakings and in order to permit the full utilization of the works constructed to accomplish the afore-

6 Cal. Stats. 1933, c. 1042, § 4.

748 STAT. 195 (1933).

850 STAT. 844,850 (1937). 
said purposes." The "reclamation of arid and semiarid lands" has always been the primary purpose of reclamation projects and in this instance financial contributions in aid of construction were obtained by the inclusion of navigation and flood control purposes, both of which are well served by the project.

In passing, attention is directed specifically to the fact that "the generation and sale of electric energy" are to provide "a means of financially aiding and assisting such undertakings." ${ }^{8}$ This particular phraseology is of importance mainly because of the fact that it is being largely ignored at present. In assigning electric energy to its role of "financially aiding and assisting" the other purposes of the project, Congress was merely giving legislative acceptance to what was generally understood by everyone connected with the proposed development. In the State Water Plan it is said that: ${ }^{10}$

These lands [Upper San Joaquin Valley] have not the financial capacity to bring in such a supply ....

The units proposed for initial development in the Great Central Valley could not be financed from revenues obtained from the sale of water and electric energy. Income from other sources inust be obtained in order to finance the development.

In drawing these conclusions, the plan showed that it was contemplated that Shasta power would be sold at about $\$ .0025$ per kilowatt hour while revenues from irrigation would be obtained from rates of $\$ 3.00$ per acre foot. Conditions have changed since those conclusions were reached. While Shasta Dam is producing-and sellimg-approximately the kilowatt hours contemplated in the plan, the power is now being sold at a rate about 5 mills instead of for approximately 2.5 mills which was expected. ${ }^{11}$

However, the major fact to be considered is that it was never expected that irrigators could or would pay all project costs directly assignable to irrigation. As was said in the State Water Plan, "many interests would be substantially benefited through the consummation of the Great Central Valley and upper San Francisco Bay project."12 The question was what means should be adopted to assess the interests benefited in order for the project to derive the financial assistance to which it was entitled.

\section{Ibid.}

10 Op. cit. supra note 2, at 56 .

11 Id. at 173 .

$12 \mathrm{Id}$. at 56. 
There is one more significant item in the legal background of the project. By direction of the legislature, ${ }^{13}$ the State Department of Finance filed claims on all unappropriated waters of the Sacramento River at Kennett and of the San Joaquin River at Friant, for the benefit of the State Water Plan. Later, at the request of the Bureau of Reclamation all rights under the filings were assigned to the United States "for the use and benefit of said Central Valley Project, California." 14 These assignments were made shortly after the bureau began construction of the project. The rights so accepted by the bureau are irrevocably attached to the Central Valley Project, but being as yet inchoate are subject to subsequent state administrative action. ${ }^{\text {ID }}$

Thus history and the law definitely establish the Central Valley Project as primarily an irrigation development.

\section{The Bureau Changes the Purpose of the Project}

Notwithstanding that irrigation legally is the primary objective of the Central Valley Project, it is fast becoming apparent that the real purpose of the bureau is to develop a federally-owned and administered commercial power system. Irrigation seems to be carried along as a necessary legal cloak.

The major result so far as irrigators are concerned is to be found in the rates they are required to pay for water. With few exceptions the "cheap water" talked about by the bureau has turned out to be the most expensive water in the state. The rates which the irrigators pay to the bureau are theoretically based on ability to pay. ${ }^{16}$ Before the rates were established, the bureau invited economists to participate in the determinations. Their conclusions based on 1939-1944 farm prices presumably are to be found in the bureau's report on the Central Valley Project. ${ }^{17}$ Statistics in that document are based on rates averaging $\$ 2.70$ per acre foot for Class I, water and $\$ 1.45$ per acre foot for Class II water. ${ }^{18}$ It would be fair to assume that these

13 Cal. Stats. 1927, c. 286.

14 Reprinted in CaL. Faras Bureau federation, Facts on the Water Rights aNd Other Issues Confronting Irrigation Agricutture 57-60 (2d ed. 1948).

15 See Cal. Water Code $\$ \S 1600-1706$.

16 In considering the rates, it should be borne in mind that they are quoted "as is" in the main canal, with the irrigators paying the cost of getting the water out of the canal and to the land. A rough approximation of the cost of water on the land is twice the canalside cost.

17 H. R. Doc. No. 146, 80th Cong., 1st Sess. (1947).

18 Class $A$, or firm, water is a supply which is reasonably dependable during the irrigation season every year; class $B$, or non-firm water, is available only at times of high stream flows and is not dependable. 
rates represent the bureau's estimate of the irrigators' ability to pay. However, the report frankly voiced doubt as to the accuracy of the conclusions and while showing the total net operating revenue from irrigation during the repayment period at $\$ 72,505,812$ on the basis of the $\$ 2.70$ and $\$ 1.45$ rates, stated that only $\$ 55,470,875$ was expected from irrigation. The reason for the discrepancy was that the higher figure was believed to exceed the irrigators' ability to pay. ${ }^{19}$ The smaller amount is $23 \%$ lower than the larger sum, and would reduce the $\$ 2.70$ rate to $\$ 2.08$ as the true bureau estimate of the irrigators' paying capabilities.

Yet the rates currently demanded by the bureau are even higher than those used in the report- $\$ 3.50$ for Class I water and $\$ 1.50$ for Class II water. The contract rate for Class I water is therefore $168 \%$ of the bureau's own estimate of the irrigators' ability to pay. The reason for these high rates is easy to find-it is the commercial power activities and program of the bureau and its attempt to establish a nationalized power system financed mainly by project water and power users.

While it maintained water rates in excess of the irrigators' ability to pay, the bureau slowed the construction of the project and awaited a favorable Congress or sufficient public pressure to appropriate funds for the completion of its commercial power system. There was nothing to prevent construction of every part of the irrigation facilities. Physical conditions at all times permitted speedy construction and the need of the upper San Joaquin Valley demanded acceleration. Congress contimually provided more money than the bureau would spend..$^{20}$ Yet in 1948, the bureau engineered a "shutdown" on the Friant-Kern canal for reasons which are still unapparent, and which cost the project nearly a million dollars in compensation to contractors. ${ }^{21}$

A review of the statements of the bureau shows its record of failure to keep promises:

1940. Commissioner Page testified that the bureau hoped to complete the project in 1946 or 1947.

10 H. R. Doc. No. 146, 80th Cong., 1st Sess. at 18 and 22 (1947).

20 This situation is in no way the responsibility of the Congress. From April 8, 1935 to June 30,1947 , Congress appropriated ample funds. This is evidenced by the fact that during that period the average unexpended balance of appropriations to the bureau for the Central Valley Project was over $\$ 12,000,000$.

21 See SEn. Rep. No. 661, 81st Cong., 1st Sess. 12 (1949). 
1941. The bureau justification for the fiscal year ending 1942 stated that the irrigation developments were expected to be completed in 1945 or 1946 .

1942. The bureau construction program indicated 1948 as the year of completion.

1944. The bureau justification estimated that Friant-Kern canal could be completed within two years of the beginning of construction.

1945. Assistant Commissioner Warne stated that the project could be completed in six years.

1947. The bureau program showed that Friant-Kern canal would be completed in 1949. and Delta-Mendota canal in 1951.

1948. Regional Director Boke testified that all main canals would be completed in 1951 and the total project in 1954.

1949. Secretary Krug advised the press that the canals would be in partial operation in 1951, with complete operation by 1955 .

1950. The bureau advised Congress that by July 1, 1951, key irrigation units of the project would have reached construction status as follows: ${ }^{22}$

Delta Cross channel-less than one-third complete.

Delta-Mendota canal-about six-sevenths complete.

Friant-Kern canal-over $\$ 3,000,000$ to go.

Tracy pumping plant-about six-sevenths complete.

Yet a statement that the bureau is incapable of speed loses force when confronted with its record of expedition in the building of facilities related to the operation of its public power system.

The first regional director for the bureau at Sacramento, Charles E. Carey, not an irrigation but an electrical engineer, frankly said on one occasion that the Central Valley Project was a power development, not an irrigation project. ${ }^{23}$ The bureau's preference for the project's commercial power features has been manifest from its beginning. The transmission line from Shasta to Oroville was built without any congressional authorization whatever. Former Secretary of the Interior Ickes, responsible for that construction, reportedly stated that he was completely devoid of interest in irrigation but intended to set up the power system. A couple of years ago the bureau commenced extending the line from Oroville to Elverta, again without au-

22 These figures are taken from the justification submitted by the bureau to Congress in the spring of 1950 at a time when the valley was being informed that the irrigation features of the project would be in operation by the middle of 1951 .

23 The statement was made at a meeting of the Board of Directors, California Farm Federation, Sept. 21, 1943. 
thorization from Congress. This line is not yet completed although it was subsequently authorized. Later, the bureau announced it would ask for bids on a switchyard specifically disapproved by Congress. ${ }^{24}$ These facilities would be useful only if the project went into the commercial power business.

The latest instance of this character was exhibited by the bureau's intiation of the West Side transmission lines. These lines were not authorized by the Congress until October 5,1949 but the plans, maps and complaint in the action in eminent domain to condemn the right of way for their construction were ready in the preceding February. The complaint even was verified at that time. ${ }^{25}$ The bureau claimed that a shortage of time required blanket condemnation suits.

In this pursuit of a federal power system, the bureau contemplates adding to the investment account of the original project over $\$ 100$,000,000 of transmission lines and steam plant. ${ }^{2 \hat{c}}$ From the standpoint of profit to the project, this investment, which is about 25 per cent of the reimbursable part of the whole project cost, will produce little, if any, additional kilowattage. ${ }^{2 \pi}$ It is claimed by the bureau that this additional investment is necessary to enable it to get a firm price for Shasta power. This claim might have substance were it not for the fact that the bureau has had for some time and now has available to it a standing offer of a firm price for virtually all of Shasta power at Shasta Dam. ${ }^{28}$

With a market for its power at over 5 mills per kilowatt hour available at Shasta Dam, the bureau continues to attempt to sell power delivered at any point within a 200 mile radius of the dam for 4.56 mills. This method of marketing commits the project to absorb sizeable transmission and substation losses which are the unavoidable incidents of transmission. Such economics do not bother the bureau which contacts every likely customer, creating support for its pro-

24 The Senate Appropriations Committee specifically disapproved Elverta switchyard and said: "Funds are not to be used for any item disapproved by the Committee." SEN. REP. No. 661, 81st Cong., 1st Sess. 12 (1949). Conferees confirmed the Senate action. H. R. REP. No. 1380, 81st Cong., 1st Sess. 17 (1949). The bureau announced it would request bids in January 1950. Reclamation Era, Sept. 1949.

25 See Verification by United States on United States v. 193.5 acres of land . . , , No. 6288 (D.C.N.D. Cal. 1949).

${ }^{26}$ See Bureau of Reclazcation Justification for the Fiscal Year 1950-1951, BR-61.

$2 \pi$ See H. R. Doc. No. 146, 80th Cong., Ist Sess. 11-12 (1947).

28 Kuder, ante at 641-643. 
gram by promising "cheap power." At the same time the available power has been offered three or four times over. ${ }^{29}$

It must be conceded that the activities referred to are inconsistent with good administration of a reclamation project, the administrators of which have been advised by counsel that it is their "first duty ... to consider the welfare of the project and water users."

\section{The Cost to the Irrigator}

As stated before, the irrigators' priniary interest is the effect of these bureau activities on the rates charged for irrigation water. These bureau activities have two principal effects:

(1) Diversion of project revenues which could be better used for repayment purposes.

(2) Increase in reimbursable investment in the project.

A brief look at the revenues which could accrue from the project under full operation is indicated. The bureau's report predicts annual gross revenues as follows: ${ }^{31}$

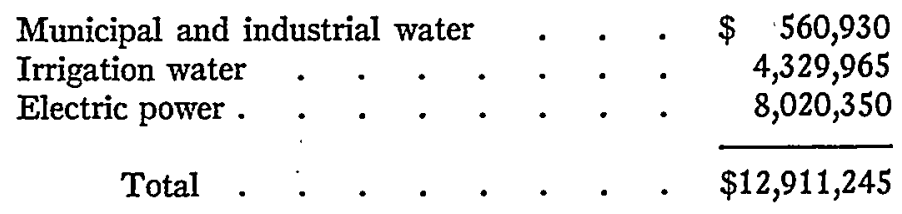

Out of this sun the report shows the Federal Treasury as receiving $\$ 4,448,981$. Thus the project will be a good revenue producer. The difficulty from the irrigators' standpoint is that it is apparent that the revenues, under the present management, will not be used in keeping with the nature of the enterprise.

An analysis of the bureau's report on the project shows that the bureau plans to divert nearly $60 \%$ of the annual revenues to its own operation, maintenance and overhead expenses. ${ }^{82}$ The average of irrigation districts in the state for this purpose is $20 \% .^{33}$ The excess could be applied to the repayment of construction costs.

The increase in the reimbursable investment account comes about

29 Power has been offered to practically every municipal power agency in California and Nevada, as well as other organizations.

3030 Or. ATr'y Gev. 197, 202 (1913). "The duty to prefer municipal purposes is secondary and incidental."

31 Taking the year 1965 as typical. H. R. Doc. No. 146, 80th Cong., 1st Sess., Tables IV and V (1947).

32 Ibid.

33 Conputed from Cac. Dept. of Pubutc Works, Div. of Water Resources, RepORT OF IRRIGATION DisTricts, Table IV (1943). 
from the proposed construction of transmission lines and a steam plant. As stated elsewhere, the proposal is made under the pretense that these facilities are essential to obtain a firm price for Shasta power. This is fallacious in view of the offer of a long time contract for Shasta power which is now and has for several years been available to the project. ${ }^{34}$ Acceptance of the offer would end the bureau's power system, so the bureau refuses the offer and proposes to sell the power elsewhere for less money, thereby increasing operating expenses. $^{35}$

Another unnecessary mcrease in investment springs from the fact that excessive current overhead is capitalized as part of the project construction cost. It was brought out in congressional hearings that the bureau is using $25 \%$ of its appropriations for overhead. ${ }^{36}$ Its own chief engineer, Walker Young, testified in 1948 that $6-8 \%$ would be generous for this purpose. ${ }^{37}$ Probably most of the extra $17 \%$ is being used by the bureau for its public power publicity campaign. ${ }^{38}$ The extra $17 \%$ is capitalized and becomes part of the reimbursable investment, repayment of which is primarily the responsibility of the irrigators.

The effect of these extravagances and diversions on the irrigators is to more than double their payments for this water which is so necessary to their survival. If the unnecessary capital investment was not made and if the project was relieved from the operating expenses and overhead accruing from the power venture, the rates charged to irrigators could be reduced from $\$ 3.50$ to $\$ 1.50$ per acre foot for Class I water, and froin $\$ 1.50$ to $\$ 0.65$ per acre foot for Class II water. These calculations are based on the total construction cost of the project as shown in the justification submitted by the bureau to support its appropriation request for the 1949-1950 fiscal year. By eliminating the transmission lines and steam plant, the reimbursable cost of the project could be cut to around $\$ 250,000,000$. Furthermore, the annual overhead, operation and maintenance expenses could be reduced with

34 See note 28 supra.

35 See text at note 29 supra.

36 Hearings before the Interior Department Subcommittee of the Senate Committee on Appropriations, Feb. 3, 1948, 80th Cong., 2d Sess. p. 796.

37 Id, at 793.

38 Perhaps a small amount is used to sugarcoat the ipecac in the water user contracts, discussed text infra at note 39 , but the necessities of the water users did that job in most instances. 
no change in gross revenues. These savings would permit the indicated reductions in water rates.

The irrigators are not merely asking for the "cheap water" promised by the bureau propaganda, or lower rates than they are equitably entitled to. They ask that the rates be reduced to levels which they can afford, levels which the bureau's own statistics seem to make obligatory. As it stands now the irrigators are being forced to sacrifice so that the bureau can nationalize the hydroelectric power resources of the Central Valley Project. They will have more money to repay, and less money with which to do it. What has been said may explain why the bureau is so desirous of including the American, Kings, Kern and Feather Rivers in the project. It also explains in part why the bureau imposes the $9(\mathrm{e})$ contract, which will now be discussed.

\section{Nationalization by Contract}

An examination of the project legislation will demonstrate that it was intended only that the bureau build the irrigation project, deliver the water according to statutory provisions, and recover the cost within the statutory period. A review of the nature of the transaction will establish that this is all the public interest requires. ${ }^{39}$

Nevertheless, the contract demanded by the bureau goes much further. The provisions: ${ }^{40}$

(1) Establish the bureau as the controller in perpetuity of the water supply.

(2) Require a surrender of water rights.

(3) Deny credit for construction cost payments even though the entire cost is fully repaid.

(4) Lack mutuality.

(5) Establish the Federal Government in business as a water utility.

(6) Control relations between irrigation districts and their members, overriding state law.

(7) Require irrigation districts to agree in advance to future rules

39 This was all the old-time Reclamation Service attempted. That service established an enviable reputation as a construction and public service agency. There scems to be nothing in changing times whicl requires the bureau to perpetuate itself as an administrative agency. Furthermore, there seems to be no reason why the irrigators should not be allowed to manage their affairs in the democratic fashion to which they are accustomed.

40 See Cal. Farm Bureau Federation, Facts and Other Issues Confronting IRRIGATION AGRICULTURE 16-51 for a typical contract. 
and regulations to be promulgated by the Secretary of the Interior. ${ }^{41}$ Analysis will show that not one of these harsh terms is of the slightest advantage to the irrigators. The California District Securities Commission felt compelled to comment with respect to one of the contracts: ${ }^{42}$

The Commission is fully cognizant of the need of the lands within the District for supplementary water and is desirous of doing everything within its power to expedite the securing of such supply, but has, in its deliberations and analysis, carefully weighed this very urgent need against surrender by the District to possible dictatorial control and regimentation. The proposed contract contains many provisions deemed not only onerous, but entirely unnecessary either for orderly administration, or to protect the government investment.

The 9 (e) contracts take their designation from a paragraph to be found in the Reclamation Project Act of 1939.43 A review of the legislative history of Section 9 (e) is enlightening. Under the original Reclamation Act of $1902^{44}$ water users at some time during their repayment period were entitled or required to take over and operate project works. Under decisions of the United States Supreme Court, the bureau functioned only as a conveyer of water, which function would presumably cease when the water users took over. ${ }^{45}$ Such a situation was apparently objectionable to the bureau, which recommended the passage of Section $9(\mathrm{e})$. The section was seemingly a provision for temporary disposition of project water. Not a word was said of it during committee hearings or on the floor of Congress. Now it develops that the bureau is using the section to change fundamental policies which have endured since 1902 . The 9 (d), or standard payment contract, gives way to the $9(\mathrm{e})$ contract which can never be paid off. The change is made not by Congress, but by an administrative agency.

The bureau has stated that the 9 (e) contract will replace the 9 (d)

41 One purpose behind the rules and regulations provision could be a desire to establish land use requirements such as have been specified in contracts of the same type in the Missouri Valley. There, the bureau claims the right to refuse water to individual farmers who fail to plant the crops and employ the irrigation practices specified by the bureau. See Cat. Farm Bureat Federatron, op. cit. supra note 40, at 69 for provisions of typical contract.

42 Report upon Examination of Contract to the Board of Directors of Coachella Valley County Water District (1947).

4353 STAT. 1187 (1939), 43 U.S. C. $\S 485$ h (1946).

4432 Stat. 388 (1902).

45 See, e.g., Nebraska v. Wyoming, 325 U. S. 589, 614 (1945). 
contract in all areas where contracts are being offered. ${ }^{40}$ Under the 9 (e) contract, the bureau ceases to be a conveyer of water and becomes the owner of the water; its tenure is im perpetuity. Its obligations with respect to the water become those which it will accept in contracts with water users instead of those fixed by statute. The necessities of the irrigators force them to relinquish by contract, rights which the Congress said they should have. Even the terms and conditions originally imposed by the contract are subject to revision by the bureau under some thirty-three encroachments on mutuality included in the contract. ${ }^{4 \pi}$ The relief from federal domination contemplated when water users started to manage their own affairs is relinquished and the bureau achieves the permanency of a governmentowned utility.

Viewed realistically, the bureau through the use of Section 9(e) has mitiated a program of nationalization of the water resources of the valley. In its relations with irrigators, it achieves the status of a superior water utility, superior because under California law, an ordinary utility functions in specified areas and under state supervision. ${ }^{48}$

${ }^{46}$ See Hearings before the Subcommittee on Interior Department Appropriations of the House Committee on Appropriations, Feb. 25 and March 4, 1947, 80th Cong., 1st Sess. 210, 734 (1947). These areas generally are the Missouri basin and California. 47 See Cat. Farm Buread Federation, op. cit. supra note 40, at 53-56 for a list.

${ }^{4 S}$ See Cal. Const. ART. XII, $\$ 23$; CaL. Gen. Laws, Act 6386 (Deering's 1944, Supp. 1949).

The bureau, by similar processes, is achieving nationalization of the power resources of the project. By law it is required to dispose of the power generated on a wholesale basis; it cannot get into the retail power business. See 53 STat. 1195 (1939), 43 U.S. C. $\S 485 \mathrm{~h}$ (1946). It is required to give preference to "municipalities and other public corporations or agencies" and to "cooperatives and other nonprofit organizations" with Rural Electrification affiliations. 53 STAT. 1195 (1939), 43 U. S. C. $\$ 485$ h (1946).

The statute does not specify how the preference shall be accomplished, so the bureau gives little effect to cost, value of service, market value of the power, or availability or more profitable disposal, in giving preferences. The extrenies to which the bureau has gone in this connection probably were responsible for the recent comment of the State of California as follows: "Preference as to purchase of power, water, or other connuodities, should be given public agencies and interests but not at preferential prices." STATE of California, Views of tere State of Califorana on Elements of a Nationat Water Resources Policy Subartited to the President's Water Resodrces Policy ComMISSION 102 (1950).

The bureau is now offering Shasta power at rates substantially under the rates of the Pacific Gas and Electric Company. The difference has been estimated by Ben Creim, former power manager for the Central Valley Project, as close to $\$ 2,500,000$ annually. Hearings before the Subcommittee on Interior Department Appropriations of the House Committee on Appropriations, 79th Cong., 1st Sess., pt. 2, p. 319 (1947). 
The Solution-Local Control

The irrigators are convinced that prevailing bureau philosophies make it useless to atteinpt to convert that agency to a different course of conduct. This conclusion has been reenforced by the bureau's attitude during water contract negotiations. The only remedy which will produce equitable results is a return of the project to the control of the State of California. Then the persons most concerned can have the type of administration they want. The original premises would be observed, the state laws respected, and water users accorded the rights to which they are entitled.

However, the bureau's contract of sale generally contains a clause requiring the purchasing agency to "construct, operate and maintain" its distribution system to the satisfaction of the Secretary of the Interior. This means that the Secretary can exercise the same extensive supervision over the contracting agency as he does over the irrigation districts under 9 (e) contracts. The provision played a large part in causing the City of Redding to reject an otherwise profitable contract for power. 